\title{
Relationship Between Students-Student Academic Interactions and Academic Achievement in Public Secondary Schools in Nakuru County, Kenya
}

\author{
Addero Wilson Ogot ${ }^{1} \quad$ Chepchieng Micah ${ }^{2} \quad$ Kariuki Mary ${ }^{2}$ \\ 1. Doctorate Student in Educational Psychology of Egerton University \\ 2. Department of Psychology, Counseling and Educational Foundations, Egerton University
}

\begin{abstract}
In achieving the set academic goals, student interacts with different group of people including their teachers, fellow students and parents with an aim of obtaining support to improve their academic realization. Through the interactions, students identify mentors who can help them achieve their academic goals and students who perform better than their peers may become role models for the rest of students in terms of academic aspirations. One of such interactions is student-student academic interactions. Academic achievement is globally paralleled as an indicator of intellectual ability of a learner in a given educational system. It is important in the determination of a students' future prospects. Educationists and other stakeholders have consistently used students' academic achievement results as basis of advancement and employment opportunities. The student-student academic interaction correspondingly shape the learning environment of students. The purpose of this study was to examine studentstudent academic interaction and academic achievement relationships in public secondary schools in Nakuru County, Kenya. Correlational research design and both quantitative and qualitative research approaches were used in the study. The population of the study comprised 23,309 form three students from 294 public secondary schools in Nakuru County. A total of 29 public secondary schools and 378 form three students were selected using stratified random sampling. The total sample size for this study was therefore 407 respondents. The study used closed-ended questionnaires to collect data from students on student-student academic interactions. Data for academic achievement was obtained from school examinations results record. Data was analyzed using the Statistical Package for Social Sciences (SPSS) version 24. The study established that there was a statistically significant relationship between student-student academic interaction and academic achievement in public secondary schools in Nakuru County, Kenya. It was concluded that student-student academic interactions are related to their academic achievement. The study recommended the
\end{abstract}


Kenya Institute of Curriculum Development (KICD) to develop a curriculum or teaching methods that seeks to improve students' academic interaction for better academic achievement.

DOI: $10.7176 / \mathrm{JEP} / 11-16-06$

Publication date:June 30th 2020

\section{Introduction}

\subsection{Background to the Study}

In achieving the set academic goals, student interacts with different group of people including their teachers, fellow students and parents with an aim of obtaining support to improve their academic realization. These groups of people basically constitute the immediate environment for students. According to Bean, Bush, McKenry, and Wilson (2013) the immediate environment of students determines how the students perform in various activities in school and out of school toward their academic achievement. This implies that the students' interactions with their environment is one of the means of learning. Ravinder (2017) posits that through interactions, students identify mentors who can help them achieve their academic goals and students who perform better than their peers may become role models for the rest of students in terms of academic aspirations. In addition students tend to associate themselves with teachers who are close to them in the process being socialized to comprehend the requirements of the curriculum (Fatih, 2016). Bean et al. (2013) asserts that parents' academic support to students is created by an interaction where the parents support the students' academic aspirations and in return the students responds by obligating to obtain high academic achievement. These forms of associations produce three types of interactions; namely; student-student academic interaction, student-teacher academic interaction, and student-parent academic interaction.

Student-student academic interaction refers to a two-way association between a student and another student in performing academic tasks in or outside the school (Schmid, Bernard, Borokhovski, Tamim, Abrami, \& Surkes, 2014). This may be in form of a student seeking academic assistance on areas that were not clear, when in need of learning resources such as a book or in class discussions and group activities. Gunnarsdóttir (2014) asserts that the level of student-student academic interaction may differ from one student to another due to several factors. This explains for different academic achievement between students in secondary schools. The academic achievement of most sub-counties of Nakuru County has been below 
the national mean grade for the years 2013-2017. In addition, Nakuru County performs poorer than other counties in Kenya (KNEC, 2017). Poor academic achievement may lead to lost opportunities in the field of academic progression. This dismal performance in academic achievement of students in Nakuru County warrants an investigation.

\subsection{Statement of the Problem}

Students' academic interaction is one of the primary means of learning. Through academic interaction the student is able to actively learn from academic based associations with the immediate environment. According to the KCSE results for the years 2013-2017, the academic achievement of secondary in Kenya has not been satisfactory despite the importance attached to success in academic work. Among the counties in Kenya, Nakuru county has consistently recorded a mean score below the national mean score as well as below the average mean score of 6.00 (C-plain) in the Kenya Certificate of Secondary Education. In addition, Nakuru County performs poorer than other similarly cosmopolitan counties in Kenya such as Kilifi, Kajiado County and Trans Nzoia County among others.

Students are constantly faced with many academic challenges as they progress in their education. In coping with these challenges they are likely to interact with their immediate environment as they seek for advice or academic assistance. Since the immediate environment of students in secondary schools is majorly composed of fellow students, this study hypothesizes that their interactions with fellow students may contribute to the variation in their academic achievement. Despite academic achievement of students in secondary schools in Kenya having drawn attention of researchers and education stakeholders, there is paucity of comprehensive and conclusive study carried out to establish the relationship between studentstudent academic interactions and academic achievement, which are the variables of the current study.

\subsection{Objective of the Study}

The objective of the study was to establish the relationship between student-student academic interaction and academic achievement in public secondary schools in Nakuru County, Kenya.

\subsection{Research Hypothesis}

H01: There is no statistically significant relationship between student-student academic interactions and academic achievement in public secondary schools in Nakuru County, 
Kenya.

\subsection{Literature ReviewStudent-Student Academic Interactions and Academic} Achievement

Interactions among student-student are vital in their academic achievement (Schmid et al., 2014). In the context of student-student interaction, Ravinder (2017) carried out a metaanalysis study in Canada on the effect of collaborative learning on enhancing student achievement. The study sought to answer the researcher question "Does collaborative learning have any statistically significant effect on student achievements outcomes?" The study found out that student to student interactions positively influenced the level of academic achievement of the students. Focusing on African schools, OECD (2015) examined how student-student interactions help in improving the performance of secondary school students. From the study, it was revealed that the interactions between students in attempting academic task improved the performance of students through the development of critical thinking.

In USA, Donohue (2017) carried out a study to examine among other aspect the influence of student individual characteristics on their academic achievement. The study revealed that the student self-learning improved the level of academic achievement of the students. The study further found out that there was a significant relationship between the student to student interactions and the student academic achievement. It was in respect to this revealed that the students that interacted more with fellow students in learning activities tended to perform better in academic examinations as compared to those who did not frequently collaborate with the fellow students in doing academic tasks in school.

A study by O'Malley (2015) carried out a study to examine how the learning environment of students affects their academic achievement in California schools. The study revealed that there was significant relationship between student-student interactions through cooperative learning and the academic achievement results. The study recommended the use of cooperative learning to increase the contact time between the students during classroom learning in order to improve the performance of this students.

In New Zealand, Cotton (2013) carried out a study to examine the influence of student interactions and their influence on their academic outcomes in secondary schools. The study results indicated that students were given opportunity to consult one another in undertaking class assignments. The study further revealed that there was a significant relationship between student-student interactions and academic achievement of students. However, it was revealed 
that top performing students did not always consult their peers but only relied on the input of their teachers.

Yaduvanshi and Singh (2018) carried out a study to examine in the opportunities provided for by cooperative learning approach. Among the aspect that the study examine is the student-student interactions in the use of cooperative learning and their influence of the academic achievement of secondary school students. Using qualitative approach in data analysis, the study found out that student-student interactions were correlated to academic achievement of students. It was further indicated that student-student interactions varied with student gender. It was in this respect established the girls interacted more with fellow students than boys did and therefore the academic achievement of girls' schools was higher than that of boys' schools.

On Nigerian context, Fatokun and Omenesa (2015) carried out a study to establish the effect of prior knowledge and classroom interactions on students' achievement in chemistry. The study found out that there was a positive relationship between student prior knowledge in Chemistry and academic interaction. The study also established that prior knowledge on Chemistry subject encouraged students to interact among themselves in sharing their level of concept understanding. This also correlated with student academic achievement.

Ekechukwu (2017) carried out a study that sought to examine the effect of student socialization on their academic achievement in secondary schools in Port Harcourt. Using correlational analysis, the study revealed that there was significant relationship between the student-student interactions and their academic achievement in end of year examinations. The study further revealed that academic achievement increased with the increase in the level of interactions among the student in classroom learning. In respect to this, the students that socialized well with their fellow student tended to perform better than those whose socialization was low.

Focusing in Kenya, Waseka and Simatwa (2016) carried out a study on student factors influencing achievement of students in secondary education in Kakamega County. Among student factors that were studied included student to student classroom interactions, peer pressure and student attitudes. The study revealed that there was a significant relationship between peer pressure among students and their academic achievement. In regard to student to student classroom interaction, the study found out that there was a positive relationship between student to student classroom interaction and their academic achievement. Ondimu (2016) also carried out a study to evaluate the influence of students' physiological needs on 
academic achievement of public secondary schools in Eastern Zone of Nakuru Municipality, Kenya. The study found out that meeting students' physiological needs determined the level of student to student interaction and this influenced their academic achievement.

\subsection{Theoretical Framework}

Self- Determination Theory was used to guide the study in regard to students' academic achievement and interactions. Self- Determination Theory was developed by (Ryan \& Patrick, 2001).The theory states that students need to feel a sense of competence, a sense of relatedness to others, and a sense of autonomy (Anderman, Midgley, Wigfield \& Eccles, 2001). When these factors are satisfied, self-motivation is enhanced and mental health, when thwarted it leads to diminished motivation and wellbeing. These psychological needs and processes are considered important in the domain of education. Competence involves having the knowledge to complete various school tasks and also believing that one can do so. Autonomy on the other hand includes initiating and regulating one's tasks. Competence enables students to feel confident, accepted, and related to those around them. This creates an environment that determines the level of interaction and whereby a student interacts with fellow students, teachers and parents. This also regulates the amount of acceptance and academic achievement of the student (Urdan \& Midgley, 2003).

The student academic interaction is an important and powerful motivator for the development of the need for competence and autonomy within the learning environment since teachers assigns students some work to accomplish. A study by (Fatih, 2016) shows that students who believe that they are competent academically are more likely to be interested in academic and school tasks. Similarly, when teachers and parents support children's basic psychological needs and provide a conducive learning environment through healthy interactions, they are simultaneously promoting more positive student-parent and studentteacher academic interactions (Wang \& Holcombe, 2010). Within this type of environment, students report greater levels of competence, autonomy, and positive relatedness as supported by this theory (Urdan \& Midgley, 2003).

Ryan and Patrick (2001) further investigated the importance of relatedness in the context of student-student academic interactions. Students spend more time with their peers than with their teachers and parents which forms friendship and more interactions that are closer and more intense than before. The results by (Ryan and Patrick, 2001) showed that the peer groups accounted for change in students' achievement in the school. Therefore this theory is 
relevant and useful in explaining student interactions in schools and how the level of interaction could affect students' academic achievement.

\subsection{Conceptual Framework}

In examining the relationship between student-student interactions and academic achievement, the study hypothesizes the association between variables as shown in Figure 1 . Other factors that this study conceptualizes to affect academic achievement was student IQ and the availability of learning resources.

Independent Variable

Intervening Variables

Dependent

Variable

\begin{tabular}{|c|c|c|}
\hline $\begin{array}{l}\text { Student-Student } \\
\text { Academic Interactions }\end{array}$ & $\begin{array}{l}\text { - Student IQ } \\
\text { - Learning } \\
\text { resources }\end{array}$ & $\begin{array}{l}\text { Academic achievement } \\
\text { - Student mean score in } \\
\text { End of Term Exams }\end{array}$ \\
\hline
\end{tabular}

Figure 1: Student-Student Academic Interactions and Academic Achievement of Students

\section{Research Methodology}

This study used correlational research design to integrate different components of the study to meet the study objectives. The study targeted 23,309 (11,938 boys and 11,371 girls) form three students, from the 294 public secondary schools in Nakuru County (Nakuru County Director of Education, 2018). In addition to the students, class teachers were also incorporated in the study. Using $10 \%$ of the target population criteria, 29 public secondary schools out of a total of 294 schools were sampled for this study. Twenty nine public secondary schools in Nakuru County were selected to participate in the study using purposive sampling. On the other hand, the sample size for form three students was 378 students that was determined using Krejcie and Morgan (1970) formula. The selection of 378 students was done using stratified sampling random sampling. Data on student-student interactions was obtained by use of closed-ended questionnaire. The instrument had a Cronbach's Alpha coefficient of 0.871 and therefore reliability was acceptable. Both descriptive and inferential statistics were used in analyzing the data. For descriptive statistics, frequencies, mean and standard deviation were used to describe basic characteristics of the data. For inferential statistics, Pearson correlation analysis was performed to test the research hypothesis. 


\subsection{Results and DiscussionStudent-Student Academic Interactions}

In respect to student-student academic interactions, the study collected data on the frequency in which students interacted with fellow students in diverse ways. This study examine ten ways in which students interacted among themselves. The ways included creation of a positive environment for learning, participation in group work discussion, motivation of one another towards better performance, asking fellow classmates for assistance to understand a concept taught in class, sharing learning resources with fellow students, paying attention to ideas shared by fellow students, consulting fellow students for academic assignments, arguing point out in regard to classwork with peers in class, minding the language student uses in interacting with fellow classmates in all academic aspects, and being accountable to fellow classmates in regard to student academic achievement in school. The above aspect were rated using a five point Likert scale whereby; Never $=0$, Rarely $=1$, Sometimes $=2$, Usually $=3$, and Always $=4$. Table 1 shows the frequencies and percentages of student-student academic interactions in public secondary schools in Nakuru County.

Focusing on the composite mean score and standard deviation of the statements assessing the extent of student to student interaction in public secondary schools in Nakuru County, the study revealed that students usually interacted well with their fellow students and that there was a moderate consensus in rating these statements. This is due to a composite mean score of 2.51 and a composite standard deviation of 0.9391 . The metric that was highly rated was the aspect of arguing points out in regard to classwork among fellow students in class. On the other hand, the metric indicating that students minded the language they used in interacting with fellow classmates in all academic aspects was poorly rated. The study further established that there was consensus among the respondents in rating the different statements on student-student academic interactions due to a standard deviation less than 1.0. Though on different contexts, the findings are in line with those by Linneman (2019) who established that student centered approaches of learning yielded more fruits than teacher centered approaches.

\subsection{Student Academic Achievement}

The study obtained the data on student academic achievement from examination records. Academic records for the previous three internal End of Term Examinations was considered in this study. Since different schools took different exams that are of different degree in complexity, the examinations mean scores were standardized using both the Z-Score and t- 
score in order to make the results comparable. The standardized results for the academic achievement were analyzed and the results presented in Table 2.

Table 1: Student-Student Academic Interactions

\begin{tabular}{|c|c|c|c|c|c|c|c|}
\hline \multirow[t]{2}{*}{ Description } & \multicolumn{5}{|c|}{ Frequency and Percentages } & \multicolumn{2}{|c|}{ Total } \\
\hline & $\mathbf{N}$ & $\mathbf{R}$ & $\mathbf{S}$ & $\mathbf{U}$ & $\mathbf{A}$ & Mean & $\begin{array}{l}\text { Std. } \\
\text { Dev }\end{array}$ \\
\hline $\begin{array}{l}\text { My fellow students create a } \\
\text { positive environment for learning }\end{array}$ & $\begin{array}{c}40 \\
(12.0 \%)\end{array}$ & $\begin{array}{c}183 \\
(55.1 \%)\end{array}$ & $\begin{array}{c}70 \\
(21.1 \%)\end{array}$ & $\begin{array}{c}20 \\
(6.0 \%)\end{array}$ & $\begin{array}{c}19 \\
(5.7 \%)\end{array}$ & 1.38 & 0.972 \\
\hline $\begin{array}{l}\text { I participate in group work } \\
\text { discussions. }\end{array}$ & $\begin{array}{c}12 \\
(3.6 \%)\end{array}$ & $\begin{array}{c}24 \\
(7.2 \%)\end{array}$ & $\begin{array}{c}34 \\
(10.2 \%)\end{array}$ & $\begin{array}{c}196 \\
(59.0 \%)\end{array}$ & $\begin{array}{c}66 \\
(19.9 \%)\end{array}$ & 2.84 & 0.945 \\
\hline $\begin{array}{l}\text { We motivate one another towards } \\
\text { better performance }\end{array}$ & $\begin{array}{c}13 \\
(3.9 \%)\end{array}$ & $\begin{array}{c}23 \\
(6.9 \%)\end{array}$ & $\begin{array}{c}32 \\
(9.6 \%)\end{array}$ & $\begin{array}{c}210 \\
(63.3 \%)\end{array}$ & $\begin{array}{c}54 \\
(16.3 \%)\end{array}$ & 2.81 & 0.925 \\
\hline $\begin{array}{l}\text { I ask my fellow classmates for } \\
\text { assistance to understand a concept } \\
\text { taught in class }\end{array}$ & $\begin{array}{c}15 \\
(4.5 \%)\end{array}$ & $\begin{array}{c}26 \\
(7.8 \%)\end{array}$ & $\begin{array}{c}47 \\
(14.2 \%)\end{array}$ & $\begin{array}{c}192 \\
(57.8 \%)\end{array}$ & $\begin{array}{c}52 \\
(15.7 \%)\end{array}$ & 2.72 & 0.972 \\
\hline $\begin{array}{l}\text { My fellow students shares } \\
\text { learning resources with me }\end{array}$ & $\begin{array}{c}11 \\
(3.3 \%)\end{array}$ & $\begin{array}{c}28 \\
(8.4 \%)\end{array}$ & $\begin{array}{c}47 \\
(14.2 \%)\end{array}$ & $\begin{array}{c}179 \\
(53.9 \%)\end{array}$ & $\begin{array}{c}67 \\
(20.2 \%)\end{array}$ & 2.79 & 0.969 \\
\hline $\begin{array}{l}\text { I pay attention to ideas shared by } \\
\text { fellow students }\end{array}$ & $\begin{array}{c}8 \\
(2.4 \%)\end{array}$ & $\begin{array}{c}21 \\
(6.3 \%)\end{array}$ & $\begin{array}{c}44 \\
(13.3 \%)\end{array}$ & $\begin{array}{c}162 \\
(48.8 \%)\end{array}$ & $\begin{array}{c}97 \\
(29.2 \%)\end{array}$ & 2.96 & 0.946 \\
\hline $\begin{array}{l}\text { I consult my fellow students for } \\
\text { academic assignments }\end{array}$ & $\begin{array}{c}10 \\
(3.0 \%)\end{array}$ & $\begin{array}{c}22 \\
(6.6 \%)\end{array}$ & $\begin{array}{c}32 \\
(9.6 \%)\end{array}$ & $\begin{array}{c}169 \\
(50.9 \%)\end{array}$ & $\begin{array}{c}99 \\
(29.8 \%)\end{array}$ & 2.98 & 0.966 \\
\hline $\begin{array}{l}\text { I argue my point out in regard to } \\
\text { classwork with my peers in class. }\end{array}$ & $\begin{array}{c}7 \\
(2.1 \%)\end{array}$ & $\begin{array}{c}11 \\
(3.3 \%)\end{array}$ & $\begin{array}{c}36 \\
(10.8 \%)\end{array}$ & $\begin{array}{c}188 \\
(56.6 \%)\end{array}$ & $\begin{array}{c}90 \\
(27.1 \%)\end{array}$ & 3.03 & 0.838 \\
\hline $\begin{array}{l}\text { I mind the language I use in } \\
\text { interacting with my fellow } \\
\text { classmates in all academic aspects }\end{array}$ & $\begin{array}{c}47 \\
(14.2 \%)\end{array}$ & $\begin{array}{c}218 \\
(65.7 \%)\end{array}$ & $\begin{array}{c}23 \\
(6.9 \%)\end{array}$ & $\begin{array}{c}28 \\
(8.4 \%)\end{array}$ & $\begin{array}{c}16 \\
(4.8 \%)\end{array}$ & 1.24 & 0.963 \\
\hline $\begin{array}{l}\text { I am accountable to my fellow } \\
\text { classmates in regard to my } \\
\text { academic achievement in school }\end{array}$ & $\begin{array}{c}35 \\
(10.5 \%)\end{array}$ & $\begin{array}{c}228 \\
(68.7 \%)\end{array}$ & $\begin{array}{c}33 \\
(9.9 \%)\end{array}$ & $\begin{array}{c}21 \\
(6.3 \%)\end{array}$ & $\begin{array}{c}15 \\
(4.5 \%)\end{array}$ & 1.26 & 0.895 \\
\hline Composite Scores & & & & & & 2.51 & 0.939 \\
\hline
\end{tabular}

Note: $\mathrm{N}=$ Never, $\mathrm{R}=$ Rarely, $\mathrm{S}=$ Sometimes, $\mathrm{U}=$ Usually, $\mathrm{A}=$ Always 
Table 2: Descriptive Statistics for Academic Achievement

\begin{tabular}{lc}
\hline Statistic & Value \\
\hline Minimum & 43.75 \\
Maximum & 76.25 \\
Mean & 60.0546 \\
Median & 59.3750 \\
Mode & 60.00 \\
Std. Deviation & 5.18680 \\
Variance & 26.903 \\
Skewness & 0.445 \\
Kurtosis & 0.274 \\
Valid N (listwise) & 332 \\
\hline
\end{tabular}

According to Table 14, the study revealed the lowest academic achievement mean score for the students who participated in this study was 43.75 marks while the highest academic achievement mean score was 76.25 marks out of a maximum score of 100 marks. This presents a range of 32.9 marks between the top student sampled in this study and the last bottom student sampled in this study. The mean average marks for the students sampled in this study was 60.0546 marks. This implied that on average students' academic achievement in public secondary schools in Nakuru County was moderately above the average mark of 50 marks. This is evidenced by a mode score of 60 marks. This implied that majority of the students score 60 marks (standardized scores) out of a possible score of 100 marks. The median academic mean score for the sample students was 59.3750. The median value was close to the mean score and the mode which then implied that the academic achievement of the students was normally distributed (Fallon, 2016). A variance of 26.903 and a standard deviation of 5.18680 was achieved in this study which therefore indicated that the academic achievement had a small deviation. This further shows that there is small disparity (Nayak, 2016) in terms of academic achievement of the sampled students in Nakuru County.

Skewness on the other hand was used to show the symmetry of data (Wooldridge, 2017). The obtained skewness was 0.445 . For a normally distributed data, the ideal skewness should be zero and therefore a skewness close to zero would imply that the data is normally distributed (Agresti, 2017). According to Clements and Sarama (2016), if the skewness is between -0.5 and 0.5 , the data is fairly symmetrical and therefore the achieved skewness in 
this study implied that the academic achievement of public secondary schools in Nakuru County was normally distributed (fairly symmetric). The achieved kurtosis for the academic achievement of students sampled in this study was 0.274 . Similarly, the kurtosis value for normally distributed data should be zero (Agresti, 2017) and therefore the academic achievement of students in public secondary schools in Nakuru County was normally distributed.

\subsection{Relationship between Student-Student Academic Interaction and Academic Achievement}

Pearson correlation analysis was performed to test the research hypothesis of the study. In order to control Type I and Type II errors, the study will select a low significance level of 0.05 . The hypothesis of the study stated that; $\mathbf{H}_{01}$ : There is no statistically significant relationship between students' academic interaction and academic achievement in public secondary schools in Nakuru County, Kenya. The results for hypothesis testing are as shown in Table 3.

Table 3: Student-Student Academic Interaction and Academic Achievement

\begin{tabular}{llc}
\hline Variable & & Student-Student \\
\hline Academic & Pearson Correlation & $0.630^{* *}$ \\
Achievement & Sig. & 0.000 \\
& $\mathrm{~N}$ & 332 \\
\hline
\end{tabular}

According to Table 3, there was statistically significant relationship between studentstudent academic interactions and student academic interaction and achievement in public secondary schools in Nakuru County. This is due to a correlation coefficient of 0.630 and a Pvalue less than the chosen significance level of $0.05(\mathrm{P}<0.05)$. Based on this finding, the first hypothesis stating that there is no significant relationship between students' academic interaction and achievement in public secondary schools in Nakuru County, Kenya was rejected at 5\% significance level. This further implied that if a student had a good interaction with fellow students, the student would likely have a good academic achievement and the vice versa.

This is in agreement to a study by Fatokun and Omenesa (2015) that found out that classroom interactions among students was correlated with student academic achievement. 
Waseka and Simatwa (2016) study also found out that there was a positive relationship between student to student classroom interaction and their academic achievement. Donohue (2017) revealed that the students that interacted more with fellow students in learning activities tended to perform better in academic examinations as compared to those who did not frequently collaborate with the fellow students in doing academic tasks in school. In contrary, a study by Ariani and Mirdad (2015) noted that there was no significant relationship between the student-students academic interactions and the academic achievement of the students. The author noted that students needed teachers in order to achieve high academic mean scores.

\section{Conclusion}

The study concluded that there was statistically significant relationship between studentstudent academic interactions and student academic achievement in public secondary schools in Nakuru County.

\section{Recommendations of the Study}

The study recommends the Kenya Institute of Curriculum Development (KICD) to develop a curriculum or teaching methods that seeks to improve the student-student academic interactions in a learning environment like competency based curriculum (CBC). The study further recommends the Ministry of Education to formulate policies by prioritizing as much as possible aspects of student-student academic interactions with an aim of proving the academic achievement of students.

\section{REFERENCES}

Agresti, A. (2017). An Introduction to Categorical Data Analysis: Second Edition. Florida: John Wiley \& Sons Publication.

Anderman, E. M., Midgley, C., Wigfield, A., \& Eccles, J. S. (2001). Learning to Value Mathematics and Reading: Relations to Mastery and Performance-Oriented Instructional Practices. Contemporary Educational Psychology, 2(6), 76-96.

Ariani, M. G., \& Mirdad, F. (2015). The Effect of School Design on Student Performance. International Education Studies, 9(1), 175.

Bean, R., Bush, R., McKenry, C., \& Wilson, M. (2013). The Impact of Parental Support, Behavioral Control, and Psychological Control on the Academic Achievement and Self-Esteem of African-American and European American Adolescents. Journal of 
Adolescent Research, 18(3), 523-541.

Clements, D. H., \& Sarama, J. (2016). Handbook of Research Methods in Early Childhood Education: Methods for Developing Scientific Education. Infonnalion Age Publishing.

Cotton, K. (2013). School Improvement Research Series: Schoolwide and Classroom Discipline. School Improvement Research Series, 1(9), 26.

Donohue, M. V. (2017). Are Individual Students' Characteristics and Academic Performance Associated with Group-Level Functioning in Educational Groups? Journal of Educational Change, 7(10), 40-49.

Ekechukwu, P. C. (2017). The Effect of Social Networking Sites on Academic Performance of Students of Abia State Polytechnic, Aba. American Journal of Art and Design, 2(4), $100-104$.

Fallon, M. (2016). Writing up Quantitative Research in the Social and Behavioral Sciences. Rotterdam: Sense Publishers.

Fatih, K. (2016). Motivation to Learn and Teacher-Student Relationship. Journal of International Education and Leadership, 6(2), 2161-7252.

Fatokun, K. V, \& Omenesa, K. A. (2015). Effect of Prior Knowledge and Classroom Interactions on Students' Achievement in Chemistry. 3(3), 184-189.

Gunnarsdóttir, H. H. (2014). Effects of Parental and Peer Support on Self-Esteem in Adolescents. Unpublished Doctorate Thesis in Arts: Reykjavik University.

Linneman, J. A. (2019). Share, Show, and Tell : Group Discussion or Simulations Versus Lecture Teaching Strategies. Teaching Sociology, 47(1), 22-31.

Nakuru County Director of Education. (2018). Kenya Certificate of Secondary Education Records. Nakuru: Kenya.

Nayak, J. K. (2016). Fundamentals of Research Methodology : Problems and Prospects. New Delhi: SSDN Publishers \& Distributors.

O’Malley, M. D. (2015). Making Sense of School Climate: Using the California School Climate, Health, and Learning (Cal-SCHLS) Survey System to Inform your School Improvement Efforts. Learning Environment Journal, 9(9), 24-48.

OECD. (2015). Equity and Quality in Education: Supporting Disadvantaged Students and Schools. https://doi.org/dx.doi.org/10.1787/9789264130852-en

Ondimu, O. (2016). Influence of Students' Physiological Needs on Academic Achievement of Public Secondary Schools in Eastern Zone of Nakuru Municipality, Kenya. Unpublished Doctor of Education Thesis: University of Nairobi. 
Ravinder, K. (2017). The Effect of Collaborative Learning on Enhancing Student Achievement: A Meta-Analysis. Unpublished Degree in Arts: Concordia University. Ryan, A. M., \& Patrick, H. (2001). The Classroom Social Environment and Changes in Adolescents' Motivation and Engagement during Middle School. American Educational Research Journal, 2(8), 437-460.

Schmid, R. F., Bernard, R. M., Borokhovski, E., Tamim, R. M., Abrami, P. C., \& Surkes, M. A. (2014). The Effects of Technology Use in Postsecondary Education: A MetaAnalysis of Classroom Applications. Computers \& Education, 7(2), 271-291.

Urdan, T., \& Midgley, C. (2003). Changes in the Perceived Classroom Goal Structure and Pattern of Adaptive Learning during Early Adolescence. Contemporary Educational Psychology, 2(8), 524-551.

Wang, M. T., \& Holcombe, R. (2010). Adolescents' Perceptions of School Environment, Engagement, and Academic Achievement in Middle School. American Educational Research Journal, 47(3), 633-662.

Waseka, L., \& Simatwa, W. (2016). Student Factors Influencing Academic Achievement of Students in Secondary Education in Kenya: A Case Study of Kakamega County. Unpublished Thesis in Education: Maseno University.

Wooldridge, J. M. (2017). Econometric Analysis of Cross Section and Panel Data. London: MIT Press.

Yaduvanshi, S., \& Singh, S. (2018). Effect of Informal Cooperative Learning Strategy in Biology Achievement on Learners of Diverse Ability. The Online Journal of New Horizons in Education, 8(2), 30-40. 